\title{
PENETAPAN KELAS KEMAMPUAN LAHAN DAS WAE BATU MERAH KOTA AMBON PROVINSI MALUKU
}

\author{
Determination of Land Capability Class in Wae Batu Merah Watershed Ambon City Maluku \\ Province
}

\author{
Dhanang Supriadi', Rafael M. Osok ${ }^{2, *}$, dan Silwanus M. Talakua ${ }^{2}$ \\ ${ }^{1}$ Program Studi Agroteknologi, Jurusan Budidaya Pertanian, Fakultas Pertanian, Universitas Pattimura \\ ${ }^{2}$ Jurusan Budidaya Pertanian, Fakultas Pertanian, Universitas Pattimura \\ Jl. Ir. M. Putuhena, Kampus Poka Ambon, 97233 \\ *Penulis Korespondensi: E-mail: rafael_osok@yahoo.com
}

\begin{abstract}
A research had been held from July till October 2016 in Wae Batu Merah Watershed, at Ambon City Maluku, Maluku Province with area covered 685,14 ha including in the area of Batu Merah Village and a part of Soya Village. The aim of the research were to: 1) determine land capability class; 2) determine land capability class with different topographyc classes, soil types and land use types; and 3) determine land use direction corresponding to each land capability class. The research method was a survey method with a pattern of synthetic and analytical approach using a flexible range of observation following the change in shape of physiography and land use. The results showed that: 1) The Wae Batu Merah Watershed has 6 land capability classes, i.e class II, III, IV, VI, VII, VIII, 2) Based on the different topography classses, soil types, and land use types it was found that land capability class with limiting factors were influenced of the three, 3) The direction of land use in the Wae Batu Merah Watershed were: intensive, middle and limited agricultural with agroforestry system, middle and limited pastural with agroforestry system, protected forest area, forest, resettlement cropping, biopore, and organic matter.
\end{abstract}

Keywords: land capability class, wae batu merah watershed

\begin{abstract}
ABSTRAK
Penelitian dilaksanakan pada bulan Juli-Oktober 2016 di DAS Wae Batu Merah Kota Ambon Provinsi Maluku dengan luas 685,14 ha yang meliputi Negeri Batu Merah dan sebagian Negeri Soya. Penelitian ini dilaksanakan dengan tujuan: 1) menetapkan kelas kemampuan lahan; 2) mengetahui kelas kemampuan lahan berdasarkan topografi, jenis tanah, dan penggunaan lahan yang berbeda; dan 3) menentukan arahan pemanfaatan lahan yang sesuai dengan masing-masing kelas kemampuan lahan. Metode penelitian adalah metode survei dengan pola pendekatan sintetik serta analitik dengan jarak observasi fleksibel mengikuti perubahan bentuk fisiografi dan penggunaan lahan. Metode penentuan kemampuan lahan adalah berdasarkan kriteria penentuan kemampuan lahan. Hasil ditemukan adalah: 1) DAS Wae Batu Merah memiliki 6 kelas kemampuan lahan, yaitu kelas kemampuan lahan II, III, IV, VI, VII, dan VIII, 2) Berdasarkan topografi, jenis tanah, dan penggunaan lahan yang berbeda ditemukan variasi kelas kemampuan lahan dengan faktor pembatas yang mempengaruhi ketiganya, 3) Arahan pemanfaatan lahan pada DAS Wae Batu Merah adalah: pertanian intensif, sedang, terbatas pola agroferestri, penggembalaan sedang, terbatas pola agroforestri, hutan lindung, hutan, tanaman pekarangan (RTH), biopori dan bahan organik.
\end{abstract}

Kata kunci: daerah aliran sungai Wae Batu Merah, kelas kemampuan lahan

\section{PENDAHULUAN}

Perkembangan pembangunan dan peningkatan jumlah penduduk yang semakin pesat, memerlukan perluasan lahan permukiman untuk tempat tinggal dan lahan pertanian untuk memenuhi kebutuhan hidup masyarakat. Salah satu sumberdaya lahan, yaitu suatu daerah aliran sungai (DAS) cenderung mendapat tekanan seiring dengan pesatnya pertumbuhan penduduk. Hal tersebut tentunya akan dapat mempengaruhi kualitas suatu DAS.

Penggunaan lahan haruslah memenuhi persyaratan yang diperlukan agar lahan tersebut dapat berproduksi serta tidak mengalami kerusakan untuk jangka waktu yang tidak terbatas (Sitorus, 1995). Kerusakan tersebut disebabkan karena kesalahan penggunaan lahan yang mengakibatkan meluasnya lahan kritis sehingga menurunkan kemampuan DAS dalam menyimpan air yang berdampak pada meningkatnya 
frekuensi banjir, erosi dan penyebaran tanah longsor pada musim penghujan dan kekeringan pada musim kemarau. Penggunaan lahan yang kurang memperhatikan asas konservasi dapat menyebabkan rusaknya tatanan DAS sehingga fungsi lahan untuk mendukung kehidupan akan berkurang.

Salah satu bentuk kegiatan yang dilakukan oleh manusia agar kerusakan DAS dapat dicegah adalah dengan memanfaatkan lahan yang ada secara optimal dengan cara menyesuaikan penggunaan lahannya dengan kemampuan tanah dan memberikan perlakuan sesuai dengan syarat-syarat yang diperlukan, agar tanah dapat berfungsi tanpa mengurangi tingkat kesuburannya yang dilakukan dalam rangka memenuhi kebutuhan hidupnya. Semakin meningkatnya jumlah penduduk maka akan semakin meningkat pula kebutuhan akan lahan dan langkanya lahan-lahan pertanian yang subur dan potensial, serta adanya persaingan penggunaan lahan antara sektor pertanian dan sektor non pertanian diperlukan adanya teknologi yang tepat guna dalam upaya mengoptimalkan penggunaan sumberdaya lahan secara berkelanjutan.

DAS Wae Batu Merah merupakan salah satu DAS di Kota Ambon yang perlu mendapatkan perhatian khusus karena telah terjadi penurunan kualitas dari DAS tersebut. Penurunan kualitas DAS ini diakibatkan karena semakin meningkatnya jumlah penduduk yang tinggal dalam lingkungan DAS Wae Batu Merah yang berakibat timbulnya masalah kualitas air, seperti pencemaran air, banjir, dan kekeringan yang semakin meningkat. Datadata mengenai kelas kemampuan lahan pada DAS Wae Batu Merah adalah penting sebagai dasar perencanaan pemanfaatan lahan yang sesuai. Oleh karena itu, perlu dibuat suatu penetapan kelas kemampuan lahan dari DAS Wae Batu Merah agar dapat diketahui seberapa besar kemampuan dari lahan tersebut, untuk selanjutnya dapat dibuat rekomendasi-rekomendasi pemanfaatan lahan guna melestarikan DAS tersebut.

Berdasarkan uraian masalah diatas, maka penelitian ini dinilai penting untuk dilaksanakan. Sehingga hasil dari penelitian dapat digunakan sebagai salah satu bahan pertimbangan untuk menentukan perencanaan atau kebijakan terhadap pemanfaatan lahan di DAS Wae Batu Merah kedepan. Penelitian ini dilakukan bertujuan untuk menetapkan kelas kemampuan lahan, mengetahui kelas kemampuan lahan berdasarkan topografi, jenis tanah, dan penggunaan lahan yang berbeda, serta menentukan pola pemanfaatan lahan yang sesuai dengan masing-masing kelas kemampuan lahan pada wilayah DAS Wae Batu Merah Kota Ambon Provinsi Maluku.

\section{METODE PENELITIAN}

Penelitian ini dilaksanakan di DAS Wae Batu Merah Kota Ambon Provinsi Maluku pada bulan Juli sampai Oktober 2016. Peralatan yang digunakan dalam penelitian ini adalah Kompas, abney level, altimeter, Soil munsell colour chart, Soil tester, Kartu deskripsi profil, Parang, Cangkul, Indikator $\mathrm{pH}$, Bor, Meter, Pisau lapang, GPS, dan alat tulis menulis. Bahan yang digunakan yaitu $\mathrm{H}_{2} \mathrm{O}_{2}, \mathrm{HCl}$ dan akuades.

\section{Pekerjaan Persiapan}

Pelaksanaan tahap pekerjaan persiapan meliputi: a) Membuat Peta Unit Lahan sebagai Peta Kerja; dan b) Informasi keadaan umum lokasi, mencari dan mengumpulkan data tentang Daerah Aliran Sungai (DAS) Wae Batu Merah, mempersiapkan alat dan bahan yang akan digunakan serta mempersiapkan administrasi perjalanan dan kebutuhan logistik.

\section{Pekerjaan Lapangan}

Metode yang digunakan adalah survey dengan pola pendekatan sintetik dan jarak observasi fleksibel mengikuti perubahan bentuk fisiografi dan penggunaan lahan pada lokasi penelitian. Pengamatan sifat morfologi tanah dilakukan melalui pengamatan boring, setelah setiap unit lahan telah diwakili dalam boring maka dilakukan pembuatan profil pewakil untuk tiap jenis tanah. Wawancara dilakukan untuk melengkapi data penelitian. Perihal yang akan ditanyakan meliputi pemanfaatan lahan, frekuensi banjir, debit/sedimentasi sungai pada musim kemarau dan hujan, kearifan lokal (sasi/kewang), dan sebagainya.

\section{Analisis Laboratorium}

Analisis tanah dilakukan di laboratorium tanah, Balai Penelitian Tanah Bogor. Analisis sampel tanah meliputi kandungan bahan organik, dan sifat-sifat fisik tanah (C-organik dan tekstur). Dalam penelitian ini data analisis tanah telah diperoleh dari Balai Pengelolaan DAS dan Hutan Lindung (BPDASHL, 2015) Wae Hapu Batu Merah.

\section{Pengolahan Data dan Penyusunan}

Kegiatan pada tahap ini meliputi: 1) Memperbaiki peta satuan lahan yang telah dibuat sebelumnya berdasarkan hasil pengamatan lapangan; 2) Membuat tabulasi data lapangan dan data laboratorium; 3) Penentuan kelas kemampuan lahan yang dilakukan dengan membandingkan data hasil pengamatan lapangan dan hasil analisis laboratorium dengan kriteria klasifikasi kemampuan lahan secara sistematik (Tabel 1); dan 4) Membuat peta kemampuan lahan DAS Wae Batu Merah berdasarkan hasil analisis data.

\section{Analisis Kemampuan Lahan}

Analisis kemampuan lahan dilakukan menggunakan metode matching. Dalam metode matching dilakukan pembandingan antara nilai faktor penghambat pada unit lahan dengan tabel konversi. Faktor penghambat tersebut adalah: kemiringan lereng, kepekaan erosi tanah, tingkat erosi, kedalaman tanah, tekstur tanah, permeabilitas, drainase, prosentase batuan/kerikil dan ancaman banjir. Untuk membantu dalam mengelompokkan kelas kemampuan, diperlukan seperangkat kriteria yang dapat menempatkan lahan ke dalam pengelompokan baik sebagai satuan kelas atau sub kelas. Lahan kemudian ditempatkan ke dalam kelas kemampuan yang sesuai berdasarkan tabel konversi yang 
ada (Tabel 1). Tabel 1. menunjukkan masing-masing jenis faktor penghambat, batas kondisi terburuk yang masih dapat diijinkan di dalam masing-masing kelas.

\section{Arahan Pemanfaatan Lahan}

Arahan pemanfaatan lahan yang sesuai didasarkan pada tabel skema hubungan antara kelas kemampuan lahan dengan intensitas dan macam penggunaan lahan. Pada setiap kelas kemampuan lahan telah terdapat besar intensitas dan macam penggunaan lahan yang sesuai. Semakin tinggi kelas kemampuan lahan berarti kualitas lahannya semakin jelek serta intensitas dan pilihan penggunaan lahan yang dapat diterapkan semakin terbatas.

\section{HASIL DAN PEMBAHASAN}

\section{Unit Lahan di DAS Wae Batu Merah}

DAS Wae Batu Merah memiliki 77 unit lahan dengan penyebaran dan karakteristik yang beragam. Topografi di DAS Wae Batu Merah jika ditinjau berdasarkan luas areal, maka topografi miring memiliki luasan yang paling besar dan tersebar dalam 16 unit lahan. Sedangkan topografi yang memiliki luasan paling kecil adalah topografi curam yang tersebar dalam 6 unit lahan.
Bahan induk atau formasi geologi yang terdapat pada DAS Wae Batu Merah terdiri dari Qa (Aluvium), Q1 (Batu gamping koral) dan Tpav (Batuan gunung api ambon). Persebaran formasi geologi Tpav (terdiri dari andesit, dasit, breksi dan tuf) memiliki luasan paling besar. Formasi geologi Tpav tersebar dalam 43 unit lahan. Sedangkan formasi geologi Qa (terdiri dari kerakal, kerikil, lanau, pasir, lempung dan sisa tumbuhan) memiliki luas persebaran yang paling kecil. Formasi geologi Qa tersebar dalam 2 unit lahan.

Jenis tanah yang terdapat pada DAS Wae Batu Merah adalah Aluvial, Gleisol, Rendzina, Litosol, Kambisol dan Podsolik. Jenis tanah aluvial tersebar dalam 2 unit lahan. Selanjutnya jenis tanah rendzina tersebar dalam 17 unit lahan. Jenis tanah litosol tersebar dalam 9 unit lahan. Untuk jenis tanah kambisol tersebar dalam 26 unit lahan. Berikutnya jenis tanah podsolik tersebar dalam 22 unit lahan.

Tipe penggunaan lahan yang terdapat pada DAS Wae Batu Merah adalah permukiman, semak belukar dan hutan lahan kering sekunder. Tipe penggunaan lahan permukiman tersebar pada 37 unit lahan. Selanjutnya untuk tipe penggunaan lahan semak belukar tersebar pada 28 unit lahan. Sedangkan tipe penggunaan lahan hutan lahan kering sekunder tersebar pada 12 unit lahan.

Tabel 1. Kriteria klasifikasi kemampuan lahan (Arsyad, 2012)

\begin{tabular}{|c|c|c|c|c|c|c|c|c|c|}
\hline \multirow{2}{*}{ No } & \multirow{2}{*}{$\begin{array}{c}\text { Faktor Penghambat / } \\
\text { Pembatas }\end{array}$} & \multicolumn{8}{|c|}{ Kelas Kemampuan lahan } \\
\hline & & I & II & III & IV & V & VI & VII & VIII \\
\hline 1 & Lereng permukaan & A & $\mathrm{B}$ & $\mathrm{C}$ & $\mathrm{D}$ & A & $\mathrm{E}$ & $\mathrm{F}$ & $\mathrm{G}$ \\
\hline 2 & Kepekaan erosi & $\mathrm{KE}_{1}, \mathrm{KE}_{2}$ & $\mathrm{KE}_{3}$ & $\mathrm{KE}_{4}, \mathrm{KE}_{5}$ & $\mathrm{KE}_{6}$ & $(*)$ & $(*)$ & $(*)$ & $(*)$ \\
\hline 3 & Tingkat erosi & $\mathrm{e}_{0}$ & $e_{1}$ & $e_{2}$ & $e_{3}$ & $(* *)$ & $\mathrm{e}_{4}$ & $e_{5}$ & $(*)$ \\
\hline 4 & Kedalaman tanah & $\mathrm{K}_{0}$ & $\mathrm{~K}_{1}$ & $\mathrm{~K}_{2}$ & $\mathrm{~K}_{2}$ & $(*)$ & $\mathrm{K}_{3}$ & $(*)$ & $(*)$ \\
\hline 5 & Tekstur lapisan atas & $\mathrm{t}_{1}, \mathrm{t}_{2}, \mathrm{t}_{3}$ & $\mathrm{t}_{1}, \mathrm{t}_{2}, \mathrm{t}_{3}$ & $\mathrm{t}_{1}, \mathrm{t}_{2}, \mathrm{t}_{3}, \mathrm{t}_{4}$ & $\mathrm{t}_{1}, \mathrm{t}_{2}, \mathrm{t}_{3}, \mathrm{t}_{4}$ & $(*)$ & $\mathrm{t}_{1}, \mathrm{t}_{2}, \mathrm{t}_{3}, \mathrm{t}_{4}$ & $\mathrm{t}_{1}, \mathrm{t}_{2}, \mathrm{t}_{3}, \mathrm{t}_{4}$ & $t_{5}$ \\
\hline 6 & Permeabilitas & $\mathrm{P}_{2}, \mathrm{P}_{3}$ & $\mathrm{P}_{2}, \mathrm{P}_{3}$ & $\mathrm{P}_{2}, \mathrm{P}_{3}, \mathrm{P}_{4}$ & $\mathrm{P}_{2}, \mathrm{P}_{3}, \mathrm{P}_{4}$ & $\mathrm{P}_{1}$ & $(*)$ & $(*)$ & $P_{5}$ \\
\hline 7 & Drainase & $\mathrm{d}_{1}$ & $d_{2}$ & $d_{3}$ & $\mathrm{~d}_{4}$ & $\mathrm{~d}_{5}$ & $(* *)$ & $(* *)$ & $\mathrm{d}_{0}$ \\
\hline 8 & Kerikil/batuan & $\mathrm{b}_{0}$ & $\mathrm{~b}_{0}$ & $b_{1}$ & $\mathrm{~b}_{2}$ & $\mathrm{~b}_{3}$ & $(*)$ & $(*)$ & $\mathrm{b}_{4}$ \\
\hline 9 & Ancaman banjir & $\mathrm{O}_{0}$ & $\mathrm{O}_{1}$ & $\mathrm{O}_{2}$ & $\mathrm{O}_{3}$ & $\mathrm{O}_{4}$ & $(* *)$ & $(* *)$ & $(*)$ \\
\hline
\end{tabular}

Catatan: $(*)$ : Dapat mempunyai sembarang sifat; $(* *)$ : Tidak berlaku sebagai parameter; $(* * *)$ : Pada umumnya berlaku di daerah iklim kering

Tabel 2. Karakteristik topografi DAS Wae Batu Merah

\begin{tabular}{|c|c|c|c|c|c|}
\hline \multirow{2}{*}{ No } & \multirow{2}{*}{ Kelas Topografi } & \multirow{2}{*}{$\begin{array}{l}\text { Kemiringan } \\
\text { Lereng }(\%)\end{array}$} & \multirow{2}{*}{ Unit Lahan } & \multicolumn{2}{|c|}{ Luas } \\
\hline & & & & $\mathrm{Ha}$ & $\%$ \\
\hline 1. & Datar & $0-3$ & $\begin{array}{l}\text { L0aA1, L0bD1, L0bD4, L0bG1, L0bG4, L0bH1, L0bH4, } \\
\text { L0dD1, L0dG1, L0dG4, L0dH1, L0dH4 }\end{array}$ & 118,49 & 17,29 \\
\hline 2. & Landai & $3-8$ & $\begin{array}{l}\text { L1aA1, L1bD1, L1bD4, L1bG1, L1bG4, L1bH1, L1bH4, } \\
\text { L1dB1, L1dD1, L1dG1, L1dG4, L1dG5, L1dH1, L1dH4, } \\
\text { L1dH5 }\end{array}$ & 149,94 & 21,88 \\
\hline 3. & Berombak & $8-15$ & $\begin{array}{l}\text { L2bD1, L2bD4, L2bG1, L2bG4, L2bH1, L2bH4, L2dD1, } \\
\text { L2dE4, L2dE5, L2dG1, L2dG4, L2dG5, L2dH1, L2dH4, } \\
\text { L2dH5 }\end{array}$ & 167,83 & 24,50 \\
\hline 4. & Bergelombang & $15-30$ & $\begin{array}{l}\text { L3bD1, L3bD4, L3bE1, L3bG1, L3bG4, L3bH1, L3bH4, } \\
\text { L3dD1, L3dE4, L3dE5, L3dG1, L3dG4, L3dG5, L3dH1, } \\
\text { L3dH4, L3dH5 }\end{array}$ & 188,51 & 27,51 \\
\hline 5. & Agak Curam & $30-45$ & $\begin{array}{l}\text { L4bD1, L4bD4, L4bG1, L4bG4, L4bH1, L4dD1, L4dE4, } \\
\text { L4dE5, L4dG1, L4dG4, L4dG5, L4dH1, L4dH4 }\end{array}$ & 51,54 & 7,52 \\
\hline 6. & Curam & $45-65$ & L5bD1, L5bG1, L5dD1, L5dE4, L5dE5, L5dG5 & 8,83 & 1,29 \\
\hline \multicolumn{4}{|c|}{ Total Luas DAS Wae Batu Merah } & 685,14 & 100,00 \\
\hline
\end{tabular}

Sumber: Data penelitian, 2016. 
Analisis Kelas Kemampuan Lahan pada DAS Wae Batu Merah

Dari hasil analisis kemampuan lahan di DAS Wae Batu Merah ditemukan enam kelas kemampuan lahan, yaitu terdiri atas kelas kemampuan lahan II, III, IV, VI, VII dan VIII. Pada setiap kelas kemampuan lahan yang ditemukan, terdapat beberapa faktor pembatas yang diantaranya adalah lereng landai sampai curam, kepekaan erosi tanah sedang, erosi ringan sampai sangat berat, kerikil dan batuan banyak, dan tekstur tanah kasar meliputi tekstur pasir berlempung dan pasir. Hasil analisis kelas kemampuan lahan di DAS Wae Batu Merah secara jelas disajikan pada Tabel 6.

Tabel 6. Kelas kemampuan lahan DAS Wae Batu Merah

\begin{tabular}{cccc}
\hline \multirow{2}{*}{ No } & Kelas & \multicolumn{2}{c}{ Luas } \\
\cline { 3 - 4 } & Kemampuan Lahan & $\mathrm{Ha}$ & $\%$ \\
\hline 1 & II & 0,43 & 0,06 \\
2 & III & 69,02 & 10,07 \\
3 & IV & 12,76 & 1,86 \\
4 & VI & 98,58 & 14,39 \\
5 & VII & 144,12 & 21,04 \\
6 & VIII & 360,21 & 52,58 \\
\hline \multicolumn{2}{c}{ Total Luas DAS Wae Batu Merah } & 685,14 & 100,00 \\
\hline
\end{tabular}

Sumber: Analisis Kemampuan Lahan DAS Wae Batu Merah, 2016.

\section{Analisis Sub Kelas Kemampuan Lahan pada DAS Wae Batu Merah}

Dari hasil analisis sub kelas kemampuan lahan, pada DAS Wae Batu Merah terdapat 12 sub kelas kemampuan lahan dari enam kelas kemampuan lahan. Hasil analisis sub kelas kemampuan lahan di DAS Wae Batu Merah selengkapnya dapat dilihat pada Tabel 7.
Dari Tabel 7 dapat dijelaskan bahwa pada DAS Wae Batu Merah terdapat 12 sub kelas kemampuan lahan dari enam kelas kemampuan lahan. Pada satu sub kelas kemampuan lahan memiliki faktor pembatas yang berbeda dangan sub kelas kemampuan lahan yang lainnya.

1. Kelas kemampuan II

Kelas kemampuan lahan II terdapat pada areal seluas 0,43 ha atau 0,06\% dari total luas DAS Wae Batu Merah. Pada kelas ini hanya terdapat satu sub kelas kemampuan lahan yaitu sub kelas kemampuan II.B $, \mathrm{KE}_{3}, \mathrm{e}_{1}$ dengan faktor pembatas berupa lereng landai (3-8 \%), kepekaan erosi tanah sedang dan erosi ringan. Sub kelas II.B, $\mathrm{KE}_{3}, \mathrm{e}_{1}$ hanya terdapat pada satu unit lahan yaitu L1dH5.

2. Kelas kemampuan III

Kelas kemampuan lahan III terdapat pada areal seluas 69,02 ha atau 10,07 \% dari total luas DAS Wae Batu Merah. Kelas ini terbagi dalam dua sub kelas kemampuan lahan, yaitu sub kelas kemampuan lahan III.e 2 dan III.C.

a. Sub kelas kemampuan lahan III.e2 memiliki luasan sebesar 60,17 ha atau $8,78 \%$. Sub kelas kemampuan lahan ini memiliki faktor pembatas berupa tingkat erosi yang terjadi sedang. Sub kelas kemampuan lahan ini tersebar dalam empat unit lahan, dimana unit lahan dengan luasan tebesar adalah L1dH4 (26,6557 ha atau 3,8906 \%) dan luasan terkecil adalah $\mathrm{LObH} 4(3,3519$ ha atau $0,4892 \%)$.

b. Sub kelas kemampuan lahan III.C memiliki luasan sebesar 8,86 ha atau 1,29\%. Sub kelas kemampuan lahan ini memiliki faktor pembatas berupa kecuraman lereng agak miring (8-15\%). Sub kelas kemampuan lahan ini terdapat hanya dalam satu unit lahan, yaitu unit lahan L2dH5.

Tabel 3. Formasi Geologi DAS Wae Batu Merah

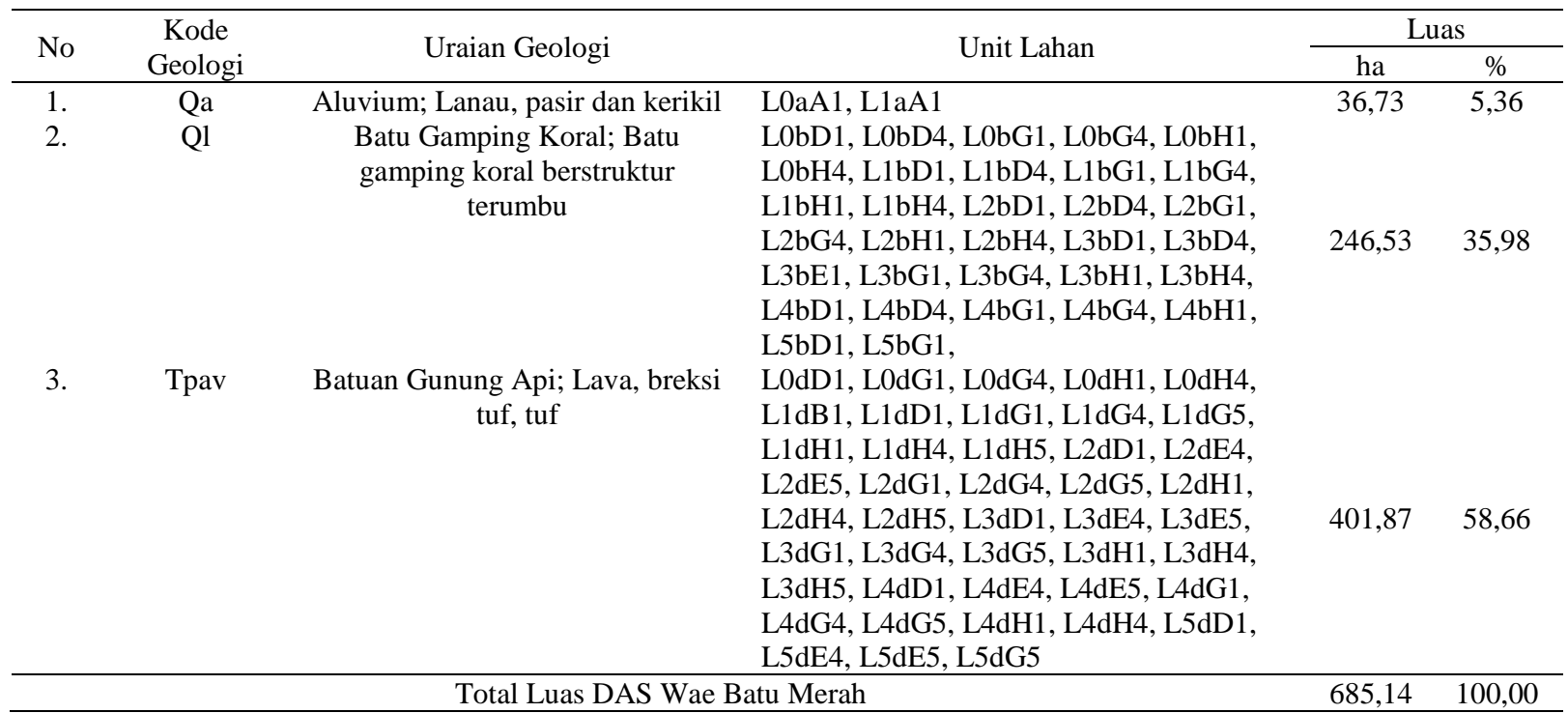

Sumber: Data penelitian, 2016. 
Tabel 4. Jenis tanah di DAS Wae Batu Merah

\begin{tabular}{|c|c|c|c|c|c|}
\hline \multirow{2}{*}{ No. } & \multicolumn{2}{|c|}{ Klasifikasi Macam Tanah } & \multirow{2}{*}{ Unit Lahan } & \multicolumn{2}{|c|}{ Luas } \\
\hline & PPT 1983 & USDA 2006 & & ha & $\%$ \\
\hline 1 & Aluvial & Typic Fluvaquents & L0aA1, L1aA1 & 36,73 & 5,36 \\
\hline 2 & Gleisol & Thapto-Histic Hydraquents & $\mathrm{L} 1 \mathrm{~dB} 1$ & 0,53 & 0,08 \\
\hline 3 & Rendzina & Lithic Haprendolls & $\begin{array}{l}\text { L0bD1, L0bD4, L0dD1, L1bD1, L1bD4, } \\
\text { L1dD1, L2bD1, L2bD4, L2dD1, L3bD1, } \\
\text { L3bD4, L3dD1, L4bD1, L4bD4, L4dD1, } \\
\text { L5bD1, L5dD1 }\end{array}$ & 71,78 & 10,48 \\
\hline 4 & Litosol & Lithic Udorthents & $\begin{array}{l}\text { L2dE4, L2dE5, L3bE1, L3dE4, L3dE5, } \\
\text { L4dE4, L4dE5, L5dE4, L5dE5 }\end{array}$ & 14,15 & 2,07 \\
\hline 5 & Kambisol & Lithic Eutrudepts & $\begin{array}{l}\text { L0bG1, L0bG4, L0dG1, L0dG4, L1bG1, } \\
\text { L1bG4, L1dG1, L1dG4, L1dG5, L2bG1, } \\
\text { L2bG4, L2dG1, L2dG4, L2dG5, L3bG1, } \\
\text { L3bG4, L3dG1, L3dG4, L3dG5, L4bG1, } \\
\text { L4bG4, L4dG1, L4dG4, L4dG5, L5bG1, } \\
\text { L5dG5 }\end{array}$ & 323,49 & 47,20 \\
\hline 6 & Podsolik & Typic Rhodudults & $\begin{array}{l}\text { L0bH1, L0bH4, L0dH1, L0dH4, L1bH1, } \\
\text { L1bH4, L1dH1, L1dH4, L1dH5, L2bH1, } \\
\text { L2bH4, L2dH1, L2dH4, L2dH5, L3bH1, } \\
\text { L3bH4, L3dH1, L3dH4, L3dH5, L4bH1, } \\
\text { L4dH1, L4dH4 }\end{array}$ & 238,47 & 34,81 \\
\hline & & Total Luas DAS Wae & Merah & 685,14 & 100,00 \\
\hline
\end{tabular}

Tabel 5. Jenis penggunaan lahan di DAS Wae Batu Merah

\begin{tabular}{|c|c|c|c|c|}
\hline \multirow{2}{*}{ No } & \multirow{2}{*}{ Jenis Penggunaan Lahan } & \multirow[b]{2}{*}{ Unit Lahan } & \multicolumn{2}{|c|}{ Luas } \\
\hline & & & ha & $\%$ \\
\hline 1. & Permukiman & $\begin{array}{l}\text { L0aA1, L0bD1, L0bG1, L0bH1, L0dD1, L0dG1, L0dH1, } \\
\text { L1aA1, L1bD1, L1bG1, L1bH1, L1dB1, L1dD1, L1dG1, } \\
\text { L1dH1, L2bD1, L2bG1, L2bH1, L2dD1, L2dG1, L2dH1, } \\
\text { L3bD1, L3bE1, L3bG1, L3bH1, L3dD1, L3dG1, L3dH1, } \\
\text { L4bD1, L4bG1, L4bH1, L4dD1, L4dG1, L4dH1, L5bD1, } \\
\text { L5bG1, L5dD1 }\end{array}$ & 408,26 & 59,59 \\
\hline 2. & Semak Belukar & $\begin{array}{l}\text { L0bD4, L0bG4, L0bH4, L0dG4, L0dH4, L1bD4, L1bG4, } \\
\text { L1bH4, L1dG4, L1dH4, L2bD4, L2bG4, L2bH4, L2dE4, } \\
\text { L2dG4, L2dH4, L3bD4, L3bG4, L3bH4, L3dE4, L3dG4, } \\
\text { L3dH4, L4bD4, L4bG4, L4dE4, L4dG4, L4dH4, L5dE4 }\end{array}$ & 215,42 & 31,44 \\
\hline 3. & Hutan Lahan Kering Sekunder & $\begin{array}{l}\text { L1dG5, L1dH5, L2dE5, L2dG5, L2dH5, L3dE5, L3dG5, } \\
\text { L3dH5, L4dE5, L4dG5, L5dE5, L5dG5 }\end{array}$ & 61,46 & 8,97 \\
\hline \multicolumn{3}{|c|}{ Total Luas DAS Wae Batu Merah } & 685,14 & 100,00 \\
\hline
\end{tabular}

3. Kelas kemampuan IV

Kelas kemampuan lahan IV terdapat pada areal seluas 12,76 ha atau $1,86 \%$ dari total luas DAS Wae Batu Merah. Kelas ini terbagi dalam tiga sub kelas kemampuan lahan, yaitu sub kelas kemampuan lahan IV. $b_{2}$, IV.D, $b_{2}$,dan IV.D.

a. Sub kelas kemampuan lahan IV.b b $_{2}$ memiliki luasan sebesar 0,0648 ha atau $0,0095 \%$. Sub kelas kemampuan lahan ini memiliki faktor pembatas berupa keberadaan kerikil dan batuan dipermukaan tanah banyak. Sub kelas kemampuan lahan ini hanya terdapat pada satu unit lahan yaitu L2dE5.

b. Sub kelas kemampuan lahan IV.D, $b_{2}$ memiliki luasan sebesar 1,8157 ha atau 0,2650 \%. Sub kelas kemampuan lahan ini memiliki faktor pembatas berupa kecuraman lereng miring $(15-30 \%)$ dan keberadaan kerikil/batuan dipermukaan tanah banyak. Sub kelas kemampuan lahan ini terdapat hanya dalam satu unit lahan, yaitu unit lahan L3dE5. c. Sub kelas kemampuan lahan IV.D memiliki luasan sebesar 10,88 ha atau $1,59 \%$. Sub kelas kemampuan lahan ini memiliki faktor pembatas berupa kecuraman lereng miring (15-30 \%). Sub kelas kemampuan lahan ini terdapat hanya dalam satu unit lahan, yaitu unit lahan L3dH5.

4. Kelas kemampuan VI

Kelas kemampuan lahan VI terdapat pada areal seluas 98,58 ha atau $14,39 \%$ dari total luas DAS Wae Batu Merah. Kelas ini terbagi dalam dua sub kelas kemampuan lahan, yaitu sub kelas kemampuan lahan VI.e $e_{4}$, dan VI.E.

a. Sub kelas kemampuan lahan VI.e 4 memiliki luasan sebesar 97,13 ha atau $14,18 \%$. Sub kelas kemampuan lahan ini memiliki faktor pembatas berupa tingkat erosi yang terjadi berat. Sub kelas kemampuan lahan ini tersebar dalam 13 unit lahan, dimana unit lahan dengan luasan tebesar adalah L2dH4 $(34,8125$ ha atau $5,0811 \%)$ dan luasan terkecil adalah L0bD4 (0,0336 ha atau 0,0049\%). 
Tabel 7. Sub kelas kemampuan lahan DAS Wae Batu Merah

\begin{tabular}{|c|c|c|c|c|c|}
\hline \multirow{2}{*}{ No } & \multirow{2}{*}{$\begin{array}{c}\text { SubKelas Kemampuan } \\
\text { Lahan }\end{array}$} & \multirow{2}{*}{ Unit Lahan } & \multirow{2}{*}{ Faktor Pembatas } & \multicolumn{2}{|c|}{ Luas } \\
\hline & & & & ha & $\%$ \\
\hline 1 & II.B,KE3,e1 & L1dH5 & $\begin{array}{l}\text { Lereng landai, kepekaan erosi } \\
\text { tanah sedang dan erosi ringan }\end{array}$ & 0,43 & 0,06 \\
\hline 2 & III.e2 & $\begin{array}{l}\text { L0bH4, L0dH4, L1bH4, } \\
\text { L1dH4 }\end{array}$ & Erosi sedang & 60,17 & 8,78 \\
\hline 3 & III.C & L2dH5 & Lereng agak miring & 8,86 & 1,29 \\
\hline 4 & IV.b2 & L2dE5 & Kerikil dan batuan banyak & 0,06 & 0,01 \\
\hline 5 & IV.D, $\mathbf{b}_{2}$ & L3dE5 & $\begin{array}{l}\text { Lereng miring, kerikil dan } \\
\text { batuan banyak }\end{array}$ & 1,82 & 0,27 \\
\hline 6 & IV.D & L3dH5 & Lereng miring & 10,88 & 1,59 \\
\hline 7 & VI.e4 & $\begin{array}{l}\text { L0bD1, L0bD4, L0bH1, } \\
\text { L0dD1, L0dH1, L1bD1, } \\
\text { L1bD4, L1bH1, L1dD1, } \\
\text { L1dH1, L2bH4, L2dE4, } \\
\text { L2dH4 }\end{array}$ & Erosi berat & 97,13 & 14,18 \\
\hline 8 & VI.E & L4dE5 & Lereng agak curam & 1,45 & 0,21 \\
\hline 9 & VII.e5 & $\begin{array}{l}\text { L1dB1, L2bD1, L2bD4, } \\
\text { L2bH1, L2dD1, L2dH1, } \\
\text { L3bE1, L3bD1, L3bD4, } \\
\text { L3bH1, L3bH4, L3dD1, } \\
\text { L3dE4, L3dH1, L3dH4, } \\
\text { L4bD1, L4bD4, L4bH1, } \\
\text { L4dD1, L4dE4, L4dH1, } \\
\text { L4dH4 }\end{array}$ & Erosi sangat berat & 141,68 & 20,68 \\
\hline 10 & VII.F,e5 & L5bD1, L5dD1, L5dE4 & $\begin{array}{l}\text { Lereng curam dan erosi } \\
\text { sangat berat }\end{array}$ & 0,82 & 0,12 \\
\hline 11 & VII.F & L5dE5 & Lereng curam & 1,62 & 0,24 \\
\hline 12 & VIII.t. & $\begin{array}{l}\text { L0aA1, L0bG1, L0bG4, } \\
\text { L0dG1, L0dG4, L1aA1, } \\
\text { L1bG1, L1bG4, L1dG1, } \\
\text { L1dG4, L1dG5, L2bG1, } \\
\text { L2bG4, L2dG1, L2dG4, } \\
\text { L2dG5, L3bG1, L3bG4, } \\
\text { L3dG1, L3dG4, L3dG5, } \\
\text { L4bG1, L4bG4, L4dG1, } \\
\text { L4dG4, L4dG5, L5bG1, } \\
\text { L5dG5 }\end{array}$ & $\begin{array}{l}\text { Tekstur tanah kasar meliputi } \\
\text { tekstur pasir berlempung dan } \\
\text { pasir }\end{array}$ & 360,21 & 52,58 \\
\hline \multicolumn{4}{|c|}{ Total Luas DAS Wae Batu Merah } & 685,14 & 100,00 \\
\hline
\end{tabular}

b. Sub kelas kemampuan lahan VI.E memiliki luasan sebesar 1,45 ha atau 0,21\%. Sub kelas kemampuan lahan ini memiliki faktor pembatas berupa kecuraman lereng agak curam (30-45\%). Sub kelas kemampuan lahan ini terdapat hanya dalam satu unit lahan, yaitu unit lahan L4dE5.

5. Kelas kemampuan VII

Kelas kemampuan lahan VII terdapat pada areal seluas 144,12 ha atau 21,04 \% dari total luas DAS Wae Batu Merah. Kelas ini terbagi dalam tiga sub kelas kemampuan lahan, yaitu sub kelas kemampuan lahan VII.e ${ }_{5}$, VII.F, $e_{5}$ dan VII.F.

a. Sub kelas kemampuan lahan VII.e e $_{5}$ memiliki luasan sebesar 141,68 ha atau 20,68\%. Sub kelas kemampuan lahan ini memiliki faktor pembatas berupa tingkat erosi yang terjadi sangat berat. Sub kelas kemampuan lahan ini tersebar dalam 22 unit lahan, dimana unit lahan dengan luasan tebesar adalah L3dH4 (30,0875 ha atau 4,3915 \%) dan luasan terkecil adalah L4bD4 $(0,0009$ ha atau $0,0001 \%)$. b. Sub kelas kemampuan lahan VII.F, $\mathrm{e}_{5}$ memiliki luasan sebesar 0,82 ha atau $0,12 \%$. Sub kelas kemampuan lahan ini memiliki faktor pembatas berupa kecuraman lereng curam (45-65\%) dan tingkat erosi yang terjadi sangat berat. Sub kelas kemampuan lahan ini tersebar dalam tiga unit lahan, dimana unit lahan dengan luasan terbesar adalah L5bD1 (0,7002 ha atau 0,1022 \%) dan luasan terkecil adalah L5dD1 $(0,0140$ ha atau $0,0020 \%$ ).

c. Sub kelas kemampuan lahan VII.F memiliki luasan sebesar 1,62 ha atau 0,24\%. Sub kelas kemampuan lahan ini memiliki faktor pembatas berupa kecuraman lereng curam (45-65\%). Sub kelas kemampuan lahan ini terdapat hanya dalam satu unit lahan, yaitu unit lahan L5dE5.

6. Kelas kemampuan VIII

Kelas kemampuan lahan VIII terdapat pada areal seluas 360,21 ha atau 52,58 \% dari total luas DAS Wae Batu Merah. Pada kelas ini hanya terdapat satu sub kelas kemampuan lahan yaitu sub kelas kemampuan VIIIt 
dengan faktor pembatas berupa tekstur tanah yang kasar meliputi tekstur tanah pasir berlempung dan pasir. Sub kelas VIIIt 5 tersebar dalam 28 unit lahan, dimana unit lahan dengan luasan terbesar adalah L3bG1 $(35,0201$ ha atau $5,1114 \%$ ) dan unit lahan dengan luasan terkecil adalah L3bG4 (0,0246 ha atau 0,0036\%).

\section{Kelas Kemampuan Lahan Berdasarkan Topografi, Jenis Tanah, dan Penggunaan Lahan yang Berbeda pada DAS Wae Batu Merah}

Unit lahan yang didapatkan dari hasil tumpang tindih (overlay) antara peta topografi, geologi, jenis tanah dan penggunaan lahan telah mendapatkan klasifikasi kelas kemampuan lahannya masing-masing. Selanjutnya, setiap kelas kemampuan lahan akan dikelompokkan berdasarkan topografi, jenis tanah dan penggunaan lahan yang berbeda. hal ini akan memungkinkan munculnya jawaban dari apa pengaruh topografi, jenis tanah dan penggunaan lahan yang berbeda terhadap faktor penghambat/pembatas pada setiap kelas kemampuan lahan di DAS Wae Batu Merah.

\section{Kelas Kemampuan Lahan Berdasarkan Topografi yang Berbeda pada DAS Wae Batu Merah}

Kemiringan lereng dinyatakan dalam derajat atau persen. Selain meningkatkan jumlah aliran permukaan, semakin curamnya lereng juga akan meningkatkan kecepatan aliran permukaan, dengan demikian memperbesar energi angkut air. Sedangkan panjang lereng dihitung mulai dari titik pangkal aliran permukaan sampai suatu tempat titik air masuk kedalam saluran atau sungai (Talakua, 2016). Dengan demikian, topografi menjadi unsur dalam faktor penghambat/pembatas kemiringan lereng permukaan dan tingkat erosi pada penentuan kelas kemampuan lahan.

Apabila dilihat dari tingkat erosi yang terjadi pada setiap kelas topografi yang ada, terdapat empat tingkat erosi yaitu erosi ringan, sedang, berat dan sangat berat. Tingkat erosi terkecil terdapat pada kelas topografi landai (3-8\%) yaitu erosi ringan, dan tingkat erosi terbesar terdapat pada kelas topografi landai sampai pada kelas topografi curam yaitu tingkat erosi sangat berat. Sedangkan jika dilihat dari rata-rata nilai erosi pada setiap kelas topografi, pada setiap kenaikan kemiringan lereng akan terjadi kenaikan nilai erosi. Menurut Anthony 2001 (dikutip Talakua, 2016), lahan yang datar biasanya lebih stabil, tetapi terjadi peningkatan kehilangan tanah dengan cepat apabila kemiringan bertambah menjadi $2 \%-5 \%$. Pada kemiringan $10 \%$, erosi akan meningkat menjadi delapan kali lebih tinggi, dan pada kemiringan lereng $15 \%$, erosi tanah telah meningkat lagi.

Kelas Kemampuan Lahan Berdasarkan Jenis Tanah yang Berbeda pada DAS Wae Batu Merah

Dalam kriteria klasifikasi kemampuan lahan (Arsyad 2012), terdapat sembilan faktor penghambat/ pembatas yang menjadi parameter penentuan kelas kemampuan lahan. Tujuh dari sembilan faktor penghambat/pembatas tersebut sangat berhubungan dengan kondisi tanah. Faktor-faktor tersebut adalah kepekaan erosi, tingkat erosi, kedalaman tanah, tekstur tanah, permeabilitas, drainase dan juga kerikil/batuan.

Pada DAS Wae Batu Merah terdapat enam jenis tanah dengan profilnya yang berbeda-beda. Setiap jenis tanah bisa menjadi salah satu faktor penentu kelas kemampuan lahan untuk suatu unit lahan.

Faktor pembatas yang ada didominasi oleh faktor pembatas tingkat erosi (ringan, sedang, berat, sangat berat). Menurut Talakua (2016) faktor tanah yang sangat berpengaruh terhadap erosi disebut erodibilitas tanah. Erodibilitas tanah adalah kemudahan suatu tanah untuk menimbulkan erosi. Jika pada tingkat energi yang sama, maka tanah yang memiliki nilai erodibilitas tinggi akan lebih mudah mengalami erosi dibandingkan tanah-tanah dengan nilai erodibilitas rendah.

Sifat-sifat tanah yang mempengaruhi erosi adalah tekstur, struktur, bahan organik, kedalaman tanah, sifat lapisan bawah dan tingkat kesuburan tanah. Tanah-tanah yang mempunyai tekstur kasar dan solum yang dalam mempunyai kapasitas infiltrasi yang tinggi sehingga kemungkinan terjadinya erosi sangat kecil. Susunan butir-butir primer membentuk tipe struktur dan dapat berpengaruh terhadap erosi. Tanah-tanah yang berstruktur granuler lebih terbuka dan akan menyerap air lebih cepat dari tanah-tanah yang susunan butir primernya lebih padat (Arsyad, 2012)

\section{Kelas Kemampuan Lahan Berdasarkan Penggunaan Lahan yang Berbeda pada DAS Wae Batu Merah}

Pada DAS Wae Batu Merah terdapat tiga jenis penggunaan lahan yang berbeda, yaitu permukiman, semak belukar, dan hutan lahan kering sekunder. Dalam kriteria klasifikasi kemampuan lahan (Arsyad, 2012), faktor penghambat/pembatas yang berhubungan dengan penggunaan lahan adalah tingkat erosi. Penentuan nilai erosi memerlukan nilai faktor vegetasi penutup atau pengelolaan tanaman (faktor $\mathrm{C}$ ). Faktor $\mathrm{C}$ inilah yang didapatkan dari data penggunaan lahan. Berikut ini merupakan tabel kelas kemampuan lahan berdasarkan penggunaan lahan yang berbeda pada DAS Wae Batu Merah.

Pada penggunaan lahan permukiman terdapat kelas kemampuan lahan dengan faktor pembatas tingkat erosi berat dan erosi sangat berat. Pada penggunaan lahan semak belukar terdapat kelas kemampuan lahan dengan faktor pembatas tingkat erosi sedang, erosi berat, dan erosi sangat berat. Sedangkan pada penggunaan lahan hutan lahan kering sekunder terdapat kelas kemampuan lahan dengan faktor pembatas tingkat erosi ringan. hal ini menunjukkan bahwa pada penggunaan lahan hutan lahan kering sekunder mempunyai nilai erosi yang lebih rendah daripada panggunaan lahan permukiman ataupun semak belukar. Menurut Stocking dan Murnaghan (2000) (dikutip Talakua, 2016) tingkat kerusakan tanah yang terjadi akibat erosi dari yang terendah sampai yang tertinggi untuk tiap penggunaan lahan adalah hutan alam, tanaman tahunan/perkebunan, tanaman semusim, dan lahan kosong. 
Pemanfaatan Lahan yang Sesuai Berdasarkan Kelas Kemampuan Lahan pada DAS Wae Batu Merah

Pada DAS Wae Batu Merah ditemukan beberapa kelas kemampuan lahan dengan faktor pembatasnya masing-masing. Arahan pemanfaatan lahan pada DAS Wae Batu Merah dibuat berdasarkan pertimbangan atas kelas kemampuan lahan serta melihat kondisi aktual setiap unit lahan. Berikut ini disajikan tabel pemanfaatan lahan yang sesuai dan arahan pemanfaatan lahan berdasarkan kelas kemampuan lahan pada DAS Wae Batu Merah.

Dari Tabel 11, pemanfaatan lahan sesuai dan arahan pemanfaatan lahan berdasarkan kelas kemampuan lahan pada DAS Wae batu Merah dapat dijelaskan sebagai berikut:

\section{Kelas Kemampuan II}

Lahan dalam kelas II memiliki beberapa hambatan yang memerlukan tindakan konservasi tanah sedang. hambatan pada Kelas II sedikit, dan tindakan yang diperlukan mudah diterapkan. Lahan ini sesuai untuk penggunaan tanaman semusim, tanaman rumput, padang penggembalaan, hutan produksi, hutan lindung, dan cagar alam (Arsyad, 2012).

Hambatan atau ancaman kerusakan pada kelas II adalah salah satu atau kombinasi dari pengaruh berikut: 1) lereng yang landai; 2) kepekaan erosi atau ancaman erosi sedang atau telah mengalami erosi sedang; 3) kedalaman tanah efektif agak dalam; 4) struktur tanah dan daya olah agak kurang baik; 5) salinitas ringan sampai sedang atau terdapat garam natrium yang mudah dihilangkan, meskipun besar kemungkinan timbul kembali; (6) kelebihan air dapat diperbaiki dengan drainase, akan tetapi tetap ada sebagai pembatas yang sedang tingkatannya; atau (7) keadaan iklim agak kurang sesuai bagi tanaman dan pengelolaan.

Kelas kemampuan lahan II terdapat pada penggunaan lahan hutan lahan kering sekunder. Penggunaan lahan yang sesuai adalah pertanian intensif. Sedangkan arahan penggunaan lahannya adalah pertanian intensif disertai dengan pola agroforestri. Pertanian intensif dapat dilakukan tanpa menghilangkan fungsi hutan yang sebenarnya. hal ini dapat dilakukan misalnya dengan menanam tanaman hortikultura bersama dengan tanaman perkebunan/hutan dalam pola agroforestri.

2. Kelas Kemampuan III

Lahan kelas III mempunyai hambatan berat yang mengurangi pilihan penggunaan atau memerlukan tindakan konservasi tanah khusus. Lahan dalam kelas III mempunyai pembatas yang lebih berat dari lahan kelas II dan jika dipergunakan bagi tanaman yang memerlukan pengelolaan tanah dan tindakan konservasi tanah biasanya lebih sulit diterapkan dan dipelihara. Lahan kelas III dapat dipergunakan untuk tanaman semusim dan tanaman yang memerlukan pengolahan tanah, tanaman rumput, padang rumput, hutan produksi, hutan lindung, dan suaka margasatwa (Arsyad, 2012). Hambatan atau ancaman kerusakan mungkin disebabkan oleh salah satu faktor atau beberapa sifat lahan berikut:

Tabel 8. Kelas kemampuan lahan DAS Wae Batu Merah berdasarkan kelas topografi

\begin{tabular}{|c|c|c|c|c|c|}
\hline \multirow{2}{*}{ No } & \multirow{2}{*}{ Kelas Topografi } & \multirow{2}{*}{$\begin{array}{c}\text { Kelas } \\
\text { Kemampuan Lahan }\end{array}$} & \multirow{2}{*}{ Unit Lahan } & \multicolumn{2}{|c|}{ Luas } \\
\hline & & & & $\mathrm{Ha}$ & $\%$ \\
\hline \multirow{3}{*}{1} & LO & III.e2 & LObH4, LOdH4 & 27,97 & 4,08 \\
\hline & Datar & VI.e4 & L0bD1, L0bD4, L0bH1, L0dD1, L0dH1 & 21,10 & 3,08 \\
\hline & $(0-3 \%)$ & VIII.t5 & L0aA1, L0bG1, L0bG4, L0dG1, L0dG4 & 69,42 & 10,13 \\
\hline \multirow{5}{*}{2} & & II.B,KE $\mathbf{E}_{3}, \mathbf{e}_{1}$ & L1dH5 & 0,43 & 0,06 \\
\hline & $\mathbf{L 1}$ & III.e2 & $\mathrm{L} 1 \mathrm{bH} 4, \mathrm{~L} 1 \mathrm{dH} 4$ & 32,19 & 4,70 \\
\hline & Landai & VI.e4 & L1bD1, L1bD4, L1bH1, L1dD1, L1dH1 & 35,24 & 5,14 \\
\hline & $(3-8 \%)$ & VII.e5 & L1dB1 & 0,53 & 0,08 \\
\hline & & VIII.t 5 & L1aA1, L1bG1, L1bG4, L1dG1, L1dG4, L1dG5 & 81,55 & 11,90 \\
\hline \multirow{5}{*}{3} & & III.C & L2dH5 & 8,86 & 1,29 \\
\hline & $\mathbf{L} 2$ & IV.b2 & L2dE5 & 0,06 & 0,01 \\
\hline & Agak miring & VI.e4 & L2bH4, L2dE4, L2dH4 & 40,79 & 5,95 \\
\hline & $(8-15 \%)$ & VII.e5 & L2bD1, L2bD4, L2bH1, L2dD1, L2dH1 & 44,99 & 6,57 \\
\hline & & VIII.t $5_{5}$ & L2bG1, L2bG4, L2dG1, L2dG4, L2dG5 & 73,13 & 10,67 \\
\hline \multirow{4}{*}{4} & & IV.D & L3dH5 & 10,88 & 1,59 \\
\hline & $\mathbf{L 3}$ & IV.D, $\mathbf{b}_{2}$ & L3dE5 & 1,82 & 0,27 \\
\hline & $\begin{array}{c}\text { Miring } \\
(15-30 \%)\end{array}$ & VII.e5 & $\begin{array}{l}\text { L3bD1, L3bD4, L3bE1, L3bH1, L3bH4, L3dD1, } \\
\text { L3dE4, L3dH1, L3dH4 }\end{array}$ & 83,92 & 12,25 \\
\hline & & VIII.t. 5 & L3bG1, L3bG4, L3dG1, L3dG4, L3dG5 & 91,89 & 13,41 \\
\hline \multirow{3}{*}{5} & L4 & VI.E & L4dE5 & 1,45 & 0,21 \\
\hline & Agak Curam & VII.e5 & L4bD1, L4bD4, L4bH1, L4dD1, L4dE4, L4dH1, L4dH4 & 12,25 & 1,79 \\
\hline & $(30-45 \%)$ & VIII.t5 & L4bG1, L4bG4, L4dG1, L4dG4, L4dG5 & 37,84 & 5,52 \\
\hline \multirow{3}{*}{6} & $\mathbf{L 5}$ & VII.F & L5dE5 & 1,62 & 0,24 \\
\hline & Curam & VII.F,es & L5bD1, L5dD1, L5dE4 & 0,82 & 0,12 \\
\hline & $(45-65 \%)$ & VIII.t5 & L5bG1, L5dG5 & 6,39 & 0,93 \\
\hline \multicolumn{4}{|c|}{ Total Luas DAS Wae Batu Merah } & 685,14 & $\mathbf{1 0 0 , 0 0}$ \\
\hline
\end{tabular}

Sumber: Analisis Kemampuan Lahan DAS Wae Batu Merah, 2016. 
1) lereng yang agak miring atau miring; 2) peka terhadap erosi atau telah mengalami erosi yang berat; 3) seringkali mengalami banjir yang merusak tanaman; 4) lapisan bawah tanah yang berpermeabilitas lambat; 5) kedalaman tanah dangkal di atas batuan, lapisan padas keras (hardpan), lapisan padas rapuh (fragipan) atau lapisan lempung padat (claypan) yang membatasi perakaran dan simpanan air; 6) terlalu basah atau masih terus jenuh air setelah didrainase; 7) kapasitas menahan air rendah; 8) salinitas atau kandungan natrium sedang; atau 9) hambatan iklim yang agak besar.

Kelas kemampuan lahan III terdapat pada penggunaan lahan hutan lahan kering sekunder dan pada penggunaan lahan semak belukar. Penggunaan lahan yang sesuai adalah pertanian sedang. Untuk lahan yang terdapat pada penggunaan lahan hutan lahan kering sekunder arahan penggunaan lahannya adalah pertanian sedang disertai dengan pola agroforestri. hal ini dapat dilakukan misalnya dengan menanam tanaman semusim bersama dengan tanaman perkebunan/hutan dalam pola agroforestri. Sedangkan untuk lahan yang terdapat pada penggunaan lahan semak belukar arahan penggunaan lahannya adalah pertanian sedang. Pemanfaatan lahan semak belukar akan lebih menghasilkan daripada lahan tersebut dibiarkan. hal ini dapat dilakukan misalnya dengan menanam tanaman semusim.

\section{Kelas Kemampuan IV}

Hambatan dan ancaman kerusakan pada lahan kelas IV lebih besar daripada kelas III, dan pilihan tanaman juga lebih terbatas. Jika dipergunakan untuk tanaman semusim diperlukan pengelolaan yang lebih hati-hati dan tindakan konservasi tanah lebih sulit diterapkan dan dipelihara, seperti teras bangku, saluran bervegetasi, dan dam pengendali, di samping tindakan yang dilakukan untuk memelihara kesuburan dan kondisi fisik tanah. Lahan di dalam kelas IV dapat dipergunakan untuk tanaman semusim dan tanaman pertanian pada umumnya, tanaman rumput, hutan produksi, padang penggembalaan, hutan lindung atau suaka alam (Arsyad, 2012). hambatan atau ancaman kerusakan lahan kelas IV disebabkan oleh salah satu atau kombinasi faktor-faktor berikut: 1) lereng miring atau relief berbukit; 2) kepekaan erosi yang besar; 3) pengaruh erosi agak berat yang telah terjadi; 4) tanahnya dangkal; 5) kapasitas menahan air yang rendah; 6) sering tergenang yang menimbulkan kerusakan berat pada tanaman; 7) kelebihan air dan ancaman kejenuhan atau penggenangan terus terjadi setelah didrainase; 8) salinitas atau kandungan natrium yang tinggi; dan 9) keadaan iklim yang kurang menguntungkan.

Kelas kemampuan lahan IV terdapat pada penggunaan lahan hutan lahan kering sekunder. Penggunaan lahan yang sesuai adalah pertanian terbatas. Sedangkan arahan penggunaan lahannya adalah pertanian terbatas disertai dengan pola agroforestri. Pertanian terbatas yang dilakukan tidak akan mengganggu keberadaan hutan yang harus dilestarikan. hal ini dapat dilakukan misalnya dengan menanam tanaman semusim yang terbatas bersama dengan tanaman perkebunan/hutan dalam pola agroforestri.

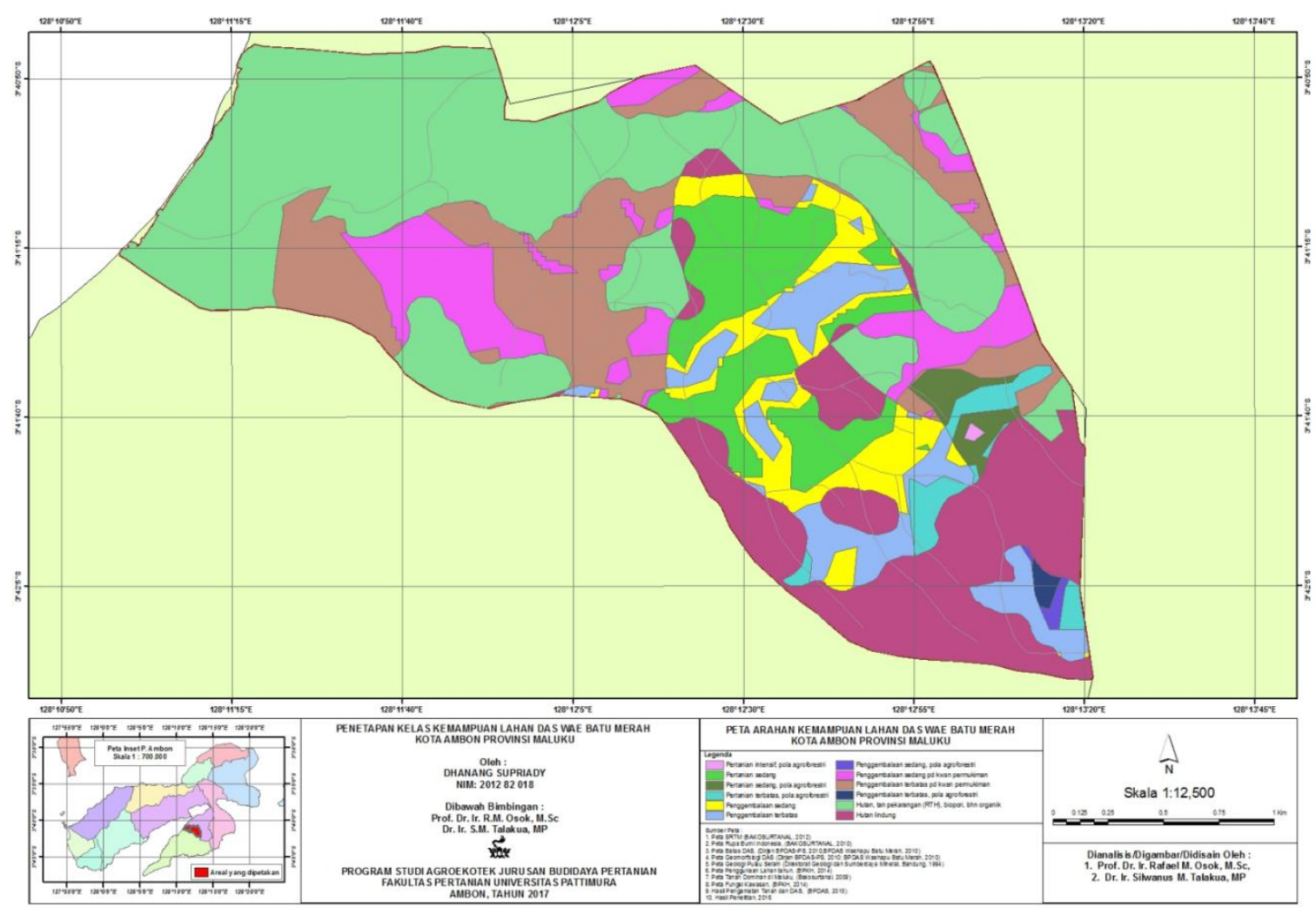

Gambar 1. Peta Arahan Kemampuan Lahan DAS Wae Batu Merah 
Tabel 9. Kelas kemampuan lahan DAS Wae Batu Merah berdasarkan jenis tanah

\begin{tabular}{|c|c|c|c|c|c|}
\hline \multirow{2}{*}{ No } & \multirow{2}{*}{ Jenis Tanah } & \multirow{2}{*}{$\begin{array}{c}\text { Kelas } \\
\text { Kemampuan Lahan } \\
\end{array}$} & \multirow{2}{*}{ Unit Lahan } & \multicolumn{2}{|c|}{ Luas } \\
\hline & & & & ha & $\%$ \\
\hline 1 & $\begin{array}{c}\text { Typic Fluvaquents } \\
\text { (Aluvial) }\end{array}$ & VIII.t5 & L0aA1, L1aA1 & 36,73 & 5,36 \\
\hline 2 & $\begin{array}{l}\text { Thapto-Histic Hydraquents } \\
\text { (Gleisol) }\end{array}$ & VII.e 5 & L1dB1 & 0,53 & 0,08 \\
\hline \multirow{3}{*}{3} & \multirow{3}{*}{$\begin{array}{l}\text { Lithic haprendolls } \\
\text { (Rendzina) }\end{array}$} & VI.e 4 & $\begin{array}{l}\text { L0bD1, L0bD4, L0dD1, L1bD1, L1bD4, } \\
\text { L1dD1 }\end{array}$ & 28,51 & 4,16 \\
\hline & & VII.e5 & $\begin{array}{l}\text { L2bD1, L2bD4, L2dD1, L3bD1, L3bD4, } \\
\text { L3dD1, L4bD1, L4bD4, L4dD1 }\end{array}$ & 42,55 & 6,21 \\
\hline & & VII.F,e5 & L5bD1, L5dD1 & 0,71 & 0,10 \\
\hline \multirow{7}{*}{4} & \multirow{7}{*}{$\begin{array}{l}\text { Lithic Udorthents } \\
\text { (Litosol) }\end{array}$} & IV.b 2 & $\mathrm{~L} 2 \mathrm{dE} 5$ & 0,06 & 0,01 \\
\hline & & IV.D, $\mathrm{b}_{2}$ & L3dE5 & 1,82 & 0,27 \\
\hline & & VI.e 4 & $\mathrm{~L} 2 \mathrm{dE} 4$ & 0,05 & 0,01 \\
\hline & & VI.E & L4dE5 & 1,45 & 0,21 \\
\hline & & VII.e $_{5}$ & L3bE1, L3dE4, L4dE4 & 9,04 & 1,32 \\
\hline & & VII.F, $\mathrm{e}_{5}$ & L5dE4 & 0,11 & 0,02 \\
\hline & & VII.F & L5dE5 & 1,62 & 0,24 \\
\hline 5 & $\begin{array}{l}\text { Lithic Eutrudepts } \\
\text { (Kambisol) }\end{array}$ & VIII.t5 & $\begin{array}{l}\text { L0bG1, L0bG4, L0dG1, L0dG4, L1bG1, } \\
\text { L1bG4, L1dG1, L1dG4, L1dG5, L2bG1, } \\
\text { L2bG4, L2dG1, L2dG4, L2dG5, L3bG1, } \\
\text { L3bG4, L3dG1, L3dG4, L3dG5, L4bG1, } \\
\text { L4bG4, L4dG1, L4dG4, L4dG5, L5bG1, } \\
\text { L5dG5 }\end{array}$ & 323,49 & 47,21 \\
\hline \multirow{7}{*}{6} & \multirow{6}{*}{$\begin{array}{l}\text { Typic Rhodudults } \\
\text { (Podsolik) }\end{array}$} & II.B, $\mathrm{KE}_{3}, \mathrm{e}_{1}$ & L1dH5 & 0,43 & 0,06 \\
\hline & & III.e 2 & LObH4, L0dH4, L1bH4, L1dH4 & 60,17 & 8,78 \\
\hline & & III.C & L2dH5 & 8,86 & 1,29 \\
\hline & & IV.D & L3dH5 & 10,88 & 1,59 \\
\hline & & VI.e4 & $\begin{array}{l}\text { L0bH1, L0dH1, L1bH1, L1dH1, L2bH4, } \\
\text { L2dH4 }\end{array}$ & 68,57 & 10,01 \\
\hline & & VII.e5 & $\begin{array}{l}\text { L2bH1, L2dH1, L3bH1, L3bH4, L3dH1, } \\
\text { L3dH4, L4bH1, L4dH1, L4dH4 }\end{array}$ & 89,57 & 13,07 \\
\hline & \multicolumn{3}{|c|}{ Total Luas DAS Wae Batu Merah } & 685,14 & 100,00 \\
\hline
\end{tabular}

Sumber: Analisis Kemampuan Lahan DAS Wae Batu Merah, 2016.

\section{Kelas Kemampuan VI}

Lahan dalam kelas VI mempunyai hambatan berat yang menyebabkan lahan ini tidak sesuai untuk penggunaan pertanian; penggunaan terbatas untuk tanaman rumput atau padang penggembalaan; hutan produksi; hutan lindung atau cagar alam. Lahan kelas VI yang terletak pada lereng agak curam jika dipergunakan untuk penggembalaan dan hutan produksi harus dikelola dengan baik untuk penggembalaan dan hutan produksi harus dikelola dengan baik untuk menghindari erosi. Beberapa tanah di dalam Kelas VI yang daerah perakarannya dalam, tetapi terletak pada lereng agak curam dapat dipergunakan untuk tanaman semusim dengan tindakan konservasi tanah yang berat (Arsyad, 2012).

Lahan dalam kelas VI mempunyai pembatas atau ancaman kerusakan yang tidak dapat dihilangkan, berupa salah satu atau kombinasi faktor-faktor berikut: 1) terletak pada lereng agak curam; 2) bahaya erosi berat; $3)$ telah tererosi berat; 4) mengandung garam larut atau natrium; 5) berbatu-batu; 6) daerah perakaran sangat dangkal; atau 7) iklim yang tidak sesuai.

Kelas kemampuan lahan VI terdapat pada penggunaan lahan hutan lahan kering sekunder, permukiman, dan penggunaan lahan semak belukar. Penggunaan lahan yang sesuai adalah penggembalaan sedang. Untuk lahan yang terdapat pada penggunaan lahan hutan lahan kering sekunder arahan penggunaan lahannya adalah penggembalaan sedang disertai dengan pola agroforestri. Penggembalaan dapat dilakukan tanpa mengurangi fungsi hutan sebenarnya. Selain itu, pola agroforestri juga akan menambah nilai produktivitas lahan tersebut. hal ini dapat dilakukan misalnya dengan berternak sedang disertai menanam tanaman penunjangnya. Untuk lahan yang terdapat pada penggunaan lahan permukiman arahan penggunaan lahannya adalah penggembalaan sedang pada kawasan permukiman. hal ini dapat dilakukan misalnya dengan berternak sedang di kawasan permukiman disertai dengan pengelolaan limbah ternak secara baik. Sedangkan untuk lahan yang terdapat pada penggunaan lahan semak belukar arahan penggunaan lahannya adalah penggembalaan sedang. Pemanfaatan lahan semak belukar akan lebih menghasilkan daripada lahan tersebut dibiarkan. hal ini dapat dilakukan misalnya dengan berternak sedang serta pengelolaan yang baik. 
Tabel 10. Kelas kemampuan lahan DAS Wae Batu Merah berdasarkan jenis penggunaan lahan

\begin{tabular}{|c|c|c|c|c|c|}
\hline \multirow{2}{*}{ No } & \multirow{2}{*}{$\begin{array}{c}\text { Jenis } \\
\text { Penggunaan Lahan }\end{array}$} & \multirow{2}{*}{$\begin{array}{c}\text { Kelas } \\
\text { Kemampuan Lahan }\end{array}$} & \multirow{2}{*}{ Unit Lahan } & \multicolumn{2}{|c|}{ Luas } \\
\hline & & & & Ha & $\%$ \\
\hline \multirow{4}{*}{1} & \multirow{4}{*}{ Permukiman } & VI.e4 & $\begin{array}{l}\text { L0bD1, L0bH1, L0dD1, L0dH1, L1bD1, L1bH1, } \\
\text { L1dD1, L1dH1 }\end{array}$ & 56,22 & 8,21 \\
\hline & & VII.e5 & $\begin{array}{l}\text { L1dB1, L2bD1, L2bH1, L2dD1, L2dH1, L3bD1, } \\
\text { L3bE1, L3bH1, L3dD1, L3dH1, L4bD1, L4bH1, } \\
\text { L4dD1, L4dH1 }\end{array}$ & 100,54 & 14,67 \\
\hline & & VII.F,e5 & L5bD1, L5dD1 & 0,71 & 0,10 \\
\hline & & VIII.t5 & $\begin{array}{l}\text { L0aA1, L0bG1, L0dG1, L1aA1, L1bG1, L1dG1, } \\
\text { L2bG1, L2dG1, L3bG1, L3dG1, L4bG1, L4dG1, } \\
\text { L5bG1 }\end{array}$ & 250,79 & 36,60 \\
\hline \multirow{5}{*}{2} & \multirow{5}{*}{ Semak Belukar } & III.e2 & L0bH4, L0dH4, L1bH4, L1dH4 & 60,17 & 8,78 \\
\hline & & VI.e4 & L0bD4, L1bD4, L2bH4, L2dE4, L2dH4 & 40,91 & 5,97 \\
\hline & & VII.e5 & $\begin{array}{l}\text { L2bD4, L3bD4, L3bH4, L3dE4, L3dH4, L4bD4, } \\
\text { L4dE4, L4dH4 }\end{array}$ & 41,14 & 6,01 \\
\hline & & VII.F,e5 & L5dE4 & 0,11 & 0,02 \\
\hline & & VIII.t5 & $\begin{array}{l}\text { L0bG4, L0dG4, L1bG4, L1dG4, L2bG4, L2dG4, } \\
\text { L3bG4, L3dG4, L4bG4, L4dG4 }\end{array}$ & 73,09 & 10,67 \\
\hline \multirow{9}{*}{3} & \multirow{8}{*}{$\begin{array}{l}\text { Hutan Lahan } \\
\text { Kering Sekunder }\end{array}$} & II.B,KE $\mathbf{E}_{3}, \mathbf{e}_{1}$ & L1dH5 & 0,43 & 0,06 \\
\hline & & III.C & L2dH5 & 8,86 & 1,29 \\
\hline & & IV.b2 & L2dE5 & 0,06 & 0,01 \\
\hline & & IV.D, $\mathbf{b}_{2}$ & L3dE5 & 1,82 & 0,27 \\
\hline & & IV.D & L3dH5 & 10,88 & 1,59 \\
\hline & & VI.E & L4dE5 & 1,45 & 0,21 \\
\hline & & VII.F & L5dE5 & 1,62 & 0,24 \\
\hline & & VIII.t5 & L1dG5, L2dG5, L3dG5, L4dG5, L5dG5 & 36,34 & 5,30 \\
\hline & & Total Luas DAS & Wae Batu Merah & 685,14 & 100,00 \\
\hline
\end{tabular}

Sumber: Analisis Kemampuan Lahan DAS Wae Batu Merah, 2016.

Tabel 11. Pemanfaatan lahan sesuai dan arahan pemanfaatan lahan berdasarkan kelas kemampuan lahan pada DAS Wae Batu Merah

\begin{tabular}{|c|c|c|c|c|c|c|}
\hline \multirow{2}{*}{ No } & \multirow{2}{*}{ KKL } & \multirow{2}{*}{ PL Sekarang } & \multirow{2}{*}{ PL Sesuai } & \multirow{2}{*}{ Arahan PL } & \multicolumn{2}{|c|}{ Luas } \\
\hline & & & & & ha & $\%$ \\
\hline 1 & II & $\begin{array}{l}\text { Hutan Lahan Kering } \\
\text { Sekunder }\end{array}$ & Pertanian Intensif & Pertanian intensif, pola agroforestri & 0,43 & 0,06 \\
\hline \multirow[t]{2}{*}{2} & \multirow[t]{2}{*}{ III } & $\begin{array}{l}\text { Hutan Lahan Kering } \\
\text { Sekunder }\end{array}$ & \multirow[t]{2}{*}{ Pertanian Sedang } & Pertanian sedang, pola agroforestri & 8,86 & 1,29 \\
\hline & & Semak Belukar & & Pertanian sedang & 60,17 & 8,78 \\
\hline 3 & IV & $\begin{array}{l}\text { Hutan Lahan Kering } \\
\text { Sekunder }\end{array}$ & Pertanian Terbatas & Pertanian terbatas, pola agroforestri & 12,76 & 1,86 \\
\hline \multirow{3}{*}{4} & \multirow{3}{*}{ VI } & $\begin{array}{l}\text { Hutan Lahan Kering } \\
\text { Sekunder }\end{array}$ & \multirow{3}{*}{ Penggembalaan Sedang } & $\begin{array}{l}\text { Penggembalaan sedang, pola } \\
\text { agroforestri }\end{array}$ & 1,45 & 0,21 \\
\hline & & Permukiman & & $\begin{array}{l}\text { Penggembalaan sedang pada kawasan } \\
\text { permukiman }\end{array}$ & 56,22 & 8,21 \\
\hline & & Semak Belukar & & Penggembalaan sedang & 40,91 & 5,97 \\
\hline \multirow{3}{*}{5} & \multirow{3}{*}{ VII } & $\begin{array}{l}\text { Hutan Lahan Kering } \\
\text { Sekunder }\end{array}$ & \multirow{3}{*}{$\begin{array}{l}\text { Penggembalaan } \\
\text { Terbatas }\end{array}$} & $\begin{array}{l}\text { Penggembalaan terbatas, pola } \\
\text { agroforestri }\end{array}$ & 1,62 & 0,24 \\
\hline & & Permukiman & & $\begin{array}{l}\text { Penggembalaan terbatas pada } \\
\text { kawasan permukiman }\end{array}$ & $\begin{array}{r}101,2 \\
5\end{array}$ & 14,78 \\
\hline & & Semak Belukar & & Penggembalaan terbatas & 41,25 & 6,02 \\
\hline \multirow{4}{*}{6} & \multirow{3}{*}{ VIII } & $\begin{array}{l}\text { Hutan Lahan Kering } \\
\text { Sekunder }\end{array}$ & \multirow{3}{*}{$\begin{array}{c}\text { Cagar Alam/Hutan } \\
\text { Lindung }\end{array}$} & Hutan lindung & 36,34 & 5,30 \\
\hline & & Permukiman & & $\begin{array}{l}\text { Hutan, tanaman pekarangan (RTH), } \\
\text { biopori, bahan organik }\end{array}$ & $\begin{array}{r}250,7 \\
9\end{array}$ & 36,60 \\
\hline & & Semak Belukar & & Hutan lindung & 73,09 & 10,67 \\
\hline & \multicolumn{4}{|c|}{ Total Luas DAS Wae Batu Merah } & $\begin{array}{c}685,1 \\
4\end{array}$ & 100,00 \\
\hline
\end{tabular}

Sumber: Analisis Kemampuan Lahan DAS Wae Batu Merah, 2016.

\section{Kelas Kemampuan VII}

Lahan kelas VII tidak sesuai untuk budidaya pertanian. Jika digunakan sebagai padang rumput atau hutan produksi harus dilakukan dengan usaha pencegahan erosi yang berat. Lahan kelas VII yang solumnya dalam dan tidak peka erosi jika dipergunakan untuk tanaman pertanian harus dibuat teras bangku yang ditunjang dengan cara-cara vegetatif untuk konservasi 
tanah, di samping tindakan pemupukan (Arsyad, 2012). Lahan kelas VII mempunyai beberapa hambatan atau ancaman kerusakan berat dan tidak dapat dihilangkan seperti: 1) terletak pada lereng yang curam; 2) telah tererosi sangat berat bahkan berupa erosi parit; dan 3) daerah perakaran sangat dangkal.

Kelas kemampuan lahan VII terdapat pada penggunaan lahan hutan lahan kering sekunder, permukiman, dan penggunaan lahan semak belukar. Penggunaan lahan yang sesuai adalah penggembalaan terbatas. Untuk lahan yang terdapat pada penggunaan lahan hutan lahan kering sekunder arahan penggunaan lahannya adalah penggembalaan terbatas disertai dengan pola agroforestri. Penggembalaan dapat dilakukan tanpa mengurangi fungsi hutan sebenarnya. Selain itu, pola agroforestri juga akan menambah nilai produktivitas lahan tersebut. hal ini dapat dilakukan misalnya dengan berternak terbatas disertai menanam tanaman penunjangnya. Untuk lahan yang terdapat pada penggunaan lahan permukiman arahan penggunaan lahannya adalah penggembalaan terbatas pada kawasan permukiman. hal ini dapat dilakukan misalnya dengan berternak terbatas di kawasan permukiman disertai dengan pengelolaan limbah ternak secara baik. Sedangkan untuk lahan yang terdapat pada penggunaan lahan semak belukar arahan penggunaan lahannya adalah penggembalaan terbatas. Pemanfaatan lahan semak belukar akan lebih menghasilkan daripada lahan tersebut dibiarkan. hal ini dapat dilakukan misalnya dengan berternak terbatas serta pengelolaan yang baik.

\section{Kelas Kemampuan VIII}

Lahan kelas VIII tidak sesuai untuk budidaya pertanian, tetapi lebih sesuai untuk dibiarkan dalam keadaan alami. Lahan kelas VIII bermanfaat sebagai hutan lindung, tempat rekreasi atau cagar alam (Arsyad, 2012). Pembatas atau ancaman kerusakan pada kelas VIII dapat berupa: 1) terletak pada lereng yang sangat curam; 2) berbatu; atau 3) kapasitas menahan air sangat rendah. Contoh lahan kelas VIII adalah tanah mati, batu tersingkap, pantai pasir, dan puncak pegunungan.

Kelas kemampuan lahan VIII terdapat pada penggunaan lahan hutan lahan kering sekunder, permukiman, dan penggunaan lahan semak belukar. Penggunaan lahan yang sesuai adalah cagar alam/hutan lindung. Untuk lahan yang terdapat pada penggunaan lahan hutan lahan kering sekunder arahan penggunaan lahannya adalah hutan lindung. hal ini dapat dilakukan dengan menjaga/melestarikan keberadaan hutan serta bila perlu ditambah penanaman pohon di kawasan tersebut. Untuk lahan yang terdapat pada penggunaan lahan permukiman arahan penggunaan lahannya adalah hutan, tanaman pekarangan (RTH), yang disertai dengan pembuatan biopori dan penggunaan bahan organik. hal ini dapat dilakukan misalnya dengan menyediakan lahan sebagai hutan kota di kawasan permukiman, menanam tanaman pekarangan yang juga akan berfungsi sebagai ruang terbuka hijau, membuat biopori di sekitar rumah serta penggunaan bahan organik. Sedangkan untuk lahan yang terdapat pada penggunaan lahan semak belukar arahan penggunaan lahannya adalah hutan lindung. Pemanfaatan lahan semak belukar akan lebih menghasilkan daripada lahan tersebut dibiarkan. Dengan mengalih fungsikan semak belukar menjadi hutan akan dapat menambah luas hutan yang telah ada, dan tentu juga akan mempengaruhi kondisi DAS secara keseluruhan terutama pada kondisi air. hal ini dapat dilakukan misalnya dengan menanam tanaman-tanaman hutan/pohon yang disertai pengelolaan kelestarian hutan yang baik.

\section{KESIMPULAN}

1. Terdapat enam kelas kemampuan lahan di DAS Wae Batu Merah, yaitu kelas kemampuan lahan II seluas 0,43 ha atau $0,06 \%$, kelas kemampuan lahan III seluas 69,02 ha atau $10,07 \%$, kelas kemampuan lahan IV seluas 12,76 ha atau $1,86 \%$, kelas kemampuan lahan VI seluas 98,58 ha atau 14,39\%, kelas kemampuan lahan VII seluas 144,12 ha atau $21,04 \%$ dan kelas kemampuan lahan VIII seluas 360,21 ha atau $52,58 \%$.

2. Dalam penelitian ini dapat diketahui kelas kemampuan lahan berdasarkan topografi, jenis tanah dan penggunaan lahan yang berbeda.

$>$ Berdasarkan kelas topografinya, kelas topografi datar (0-3 \%) memiliki kelas kemampuan lahan III.e 2 , VI.e 4 , VIII.t5. Kelas topografi landai (3-8 $\%)$ memiliki kelas kemampuan lahan

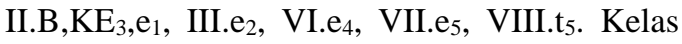
topografi berombak (8-15\%) memiliki kelas kemampuan lahan III.C, IV.b ${ }_{2}$, VI.e 4 , VII.e 5 , VIII.t5. Kelas topografi bergelombang (15-30 $\%)$ memiliki kelas kemampuan lahan IV.D, IV.D, $b_{2}$, VII.e , VIII.t. $_{5}$. Kelas topografi agak curam (30-45 \%) memiliki kelas kemampuan lahan VI.E, VII.e 5 , VIII.t5. Kelas topografi curam (45-65\%) memiliki kelas kemampuan lahan VI.F, VII.F,e 5 , VIII.ts.

$>$ Berdasarkan jenis tanahnya, Jenis tanah Typic Fluvaquents (Aluvial) memiliki kelas kemampuan lahan VIII.t. t . Jenis tanah ThaptoHistic Hydraquents (Gleisol) memiliki kelas kemampuan lahan VII.e. Jenis tanah Lithic haprendolls (Rendzina) memiliki kelas kemampuan lahan VI.e 4 , VII.e 5 , VII.F,e, e. Jenis tanah Lithic Udorthents (Litosol) memiliki kelas kemampuan lahan IV.b ${ }_{2}$, IV.D, $\mathrm{b}_{2}$, VI.e.

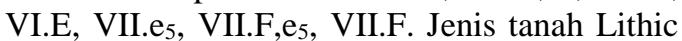
Eutrudepts (Kambisol) memiliki kelas kemampuan lahan VIII.t5. Jenis tanah Typic Rhodudults (Podsolik) memiliki kelas kemampuan lahan II.B, $\mathrm{KE}_{3} \mathrm{e}_{1}$, III.e $\mathrm{e}_{2}$, III.C, IV.D, VI.e 4 , VII.e 5 .

> Berdasarkan penggunaan lahannya, Penggunaan lahan permukiman memiliki kelas kemampuan lahan VI.e , $_{4} \quad$ VII.e 5 , VII.F, $\mathrm{e}_{5}$, VIII.t. Penggunaan lahan semak belukar memiliki kelas kemampuan lahan III.e $e_{2}, V_{1} . e_{4}$, VII.e 5 , VII.F,e 5 , VIII.t. 5 . Penggunaan lahan hutan lahan kering sekunder memiliki kelas kemampuan lahan II.B, $\mathrm{KE}_{3} \mathrm{e}_{1}$, III.C, IV.b ${ }_{2}$, IV.Db ${ }_{2}$, IV.D, VI.E, VII.F, VIII.t5. 
3. Arahan pemanfaatan lahan pada DAS Wae Batu Merah dibuat berdasarkan pertimbangan atas kelas kemampuan lahan serta melihat kondisi aktual setiap unit lahan.

$>$ Kelas kemampuan lahan II terdapat pada penggunaan lahan hutan lahan kering sekunder. Penggunaan lahan yang sesuai adalah pertanian intensif. Sedangkan arahan penggunaan lahannya adalah pertanian intensif disertai dengan pola agroforestri.

$>$ Kelas kemampuan lahan III terdapat pada penggunaan lahan hutan lahan kering sekunder dan pada penggunaan lahan semak belukar. Penggunaan lahan yang sesuai adalah pertanian sedang. Untuk lahan yang terdapat pada penggunaan lahan hutan lahan kering sekunder arahan penggunaan lahannya adalah pertanian sedang disertai dengan pola agroforestri. Sedangkan untuk lahan yang terdapat pada penggunaan lahan semak belukar arahan penggunaan lahannya adalah pertanian sedang.

$>$ Kelas kemampuan lahan IV terdapat pada penggunaan lahan hutan lahan kering sekunder. Penggunaan lahan yang sesuai adalah pertanian terbatas. Sedangkan arahan penggunaan lahannya adalah pertanian terbatas disertai dengan pola agroforestri.

$>$ Kelas kemampuan lahan VI terdapat pada penggunaan lahan hutan lahan kering sekunder, permukiman, dan penggunaan lahan semak belukar. Penggunaan lahan yang sesuai adalah penggembalaan sedang. Untuk lahan yang terdapat pada penggunaan lahan hutan lahan kering sekunder arahan penggunaan lahannya adalah penggembalaan sedang disertai dengan pola agroforestri. Untuk lahan yang terdapat pada penggunaan lahan permukiman arahan penggunaan lahannya adalah penggembalaan sedang pada kawasan permukiman. Sedangkan untuk lahan yang terdapat pada penggunaan lahan semak belukar arahan penggunaan lahannya adalah penggembalaan sedang.

> Kelas kemampuan lahan VII terdapat pada penggunaan lahan hutan lahan kering sekunder, permukiman, dan penggunaan lahan semak belukar. Penggunaan lahan yang sesuai adalah penggembalaan terbatas. Untuk lahan yang terdapat pada penggunaan lahan hutan lahan kering sekunder arahan penggunaan lahannya adalah penggembalaan terbatas disertai dengan pola agroforestri. Untuk lahan yang terdapat pada penggunaan lahan permukiman arahan penggunaan lahannya adalah penggembalaan terbatas pada kawasan permukiman. Sedangkan untuk lahan yang terdapat pada penggunaan lahan semak belukar arahan penggunaan lahannya adalah penggembalaan terbatas.

$>$ Kelas kemampuan lahan VIII terdapat pada penggunaan lahan hutan lahan kering sekunder, permukiman, dan penggunaan lahan semak belukar. Penggunaan lahan yang sesuai adalah cagar alam/hutan lindung. Untuk lahan yang terdapat pada penggunaan lahan hutan lahan kering sekunder arahan penggunaan lahannya adalah hutan lindung. Untuk lahan yang terdapat pada penggunaan lahan permukiman arahan penggunaan lahannya adalah hutan, tanaman pekarangan (RTH), yang disertai dengan pembuatan biopori dan penggunaan bahan organik. Sedangkan untuk lahan yang terdapat pada penggunaan lahan semak belukar arahan penggunaan lahannya adalah hutan lindung.

\section{DAFTAR PUSTAKA}

Arsyad, S. 2012. Konservasi Tanah dan Air. IPB Press, Bogor.

BPDASHL. 2015. Identifikasi Karakteristik DAS Wae Batu Merah. Balai Pengelolaan DAS dan Hutan Lindung Wae Hapu Batu Merah. Dirjen PDASHL, Kementerian Lingkungan Hidup dan Kehutanan.

Sitorus. 1995. Evaluasi Sumberdaya Lahan. Tarsito, Bandung.

Talakua, S.M. 2016. Degradasi Lahan Metode Analisis dan Aplikasinya dalam Penggunaan Lahan. Plantaxia. Yogyakarta. 